\title{
Precancerous Polyp
}

National Cancer Institute

\section{Source}

National Cancer Institute. Precancerous Polyp. NCI Thesaurus. Code C8587.

A polyp with severe dysplastic features. 